\title{
IMPLEMENTASI KEBIJAKAN PEMUNGUTAN PAJAK HOTEL KATEGORI RUMAH KOS DI KOTA MALANG
}

\author{
Selly Novicadisa, Sjamsiar Sjamsuddin, Suryadi \\ Program M agister IImu A dministrasi Publik, U niversitas B rawijaya, JI. V eteran M alang \\ Email. sellynovicadisa@gmail.com
}

\begin{abstract}
ABSTRAK
Penelitian ini bertujuan untuk mengetahui implementasi Perda Kota M alang Nomor 16 Tahun 2010 tentang pemungutan pajak hotel kategori rumah kos di kota malang. L atar belakang dari penelitian ini adalah tuntutan pemaksimalan perolehan pendapatan asli daerah sebagai bentuk proses desentralisasi di Indonesia. Pemerintah kota Malang melihat potensi sebaran rumah kos di wilayahnya sebagai dampak dari banyaknya perguruan tinggi dan potensi wisata di kota $\mathrm{M}$ alang dapat dimanfaatkan dengan menarik pajak dari potensi tersebut. Perlu dikaji apakah implementasi pemungutan pajak hotel kategori kos sudah sesuai dengan peraturan yang ada dan mencapai target nya. Penelitian ini merupakan penelitian deskriptif dengan menggunakan pendekatan kualitatif. Peneliti menggunakan metode pengumpulan data melalui wawancara, observasi dan dokumentasi. Hasil dari penelitian ini yaitu secara umum implementasi Perda Nomor 16 Tahun 2010 tentang pemungutan pajak hotel kategori rumah kos di Kota M alang sudah berjalan dengan efektif namun tidak efisien. Penyebab utamanya adalah bentuk komunikasi antara implementor dan sasaran yang belum terjalin dengan baik. Peraturan yang lebih terperinci terkait penarikan pajak hotel kategori rumah kos juga dirasa diperlukan, karena akan membantu implementor dalam menjalankan kebijakan ini yang tergolong masih baru di kota M alang.
\end{abstract}

Kata Kunci: Implementasi kebijakan, Pemungutan pajak, Pajak hotel kategori rumah kos

\begin{abstract}
This study aims to determine the implementation of Local Regulation No. 16 Year 2010 on hotel taxation, boarding house category in Malang city. The background of this study is the maximization demands acquisition of local revenue as a form of decentralization process in Indonesia. Malang city government saw the potential distribution of a rooming house on its territory as a result of the many universities and the potential for tourism in the city of Malang can be used to collect taxes from this potentiality. Need to assess whether the implementation of tax collection kos hotels category is in conformity with the existing regulations. This research is a descriptive study using a qualitative approach. Researchers collects data through interviews, observation and documentation. The results of this study are generally the implementation of Regulation No. 16 Year 2010 has been running with effective but not efficient. The main cause is a form of communication between the implementor and the target has not been established. More detailed regulations related to taxation category hotel rooming house is also considered necessary, as it will help the implementor in carrying out this policy which is still relatively new in the city of Malang.
\end{abstract}

Keywords: Policy implementation, Taxes collecting, Hotel taxes boarding house category.

\section{PENDAHULUAN}

Pemaksimalan pendapatan asli daerah (PAD) sebagai bentuk pelaksanaan asas desentralisasi (otonomi daerah) bagi kabupaten/kota merupakan upaya untuk mengurangi ketergantungan daerah kepada pusat. Dengan tercapainya perolehan PAD yang maksimal maka pemerintah kabupaten/kota akan memiliki keleluasaan dalam mengalokasikan dana yang 
dibutuhkan oleh pemerintah dalam menjalankan pemerintahan dan pelayanan yang baik.K egiatan Pemerintah yang berlangsung terus menerus dan berkesinambungan bertujuan untuk meningkatkan kesejahteraan rakyat baik moril maupun materil. Oleh karena itu, Pemerintah Daerah berhak mengenakan pungutan kepada masyarakatnya.

Salah satu pungutan yang dilaksanakan oleh kabupaten dan kota adalah pajak daerah dan retribusi daerah. Dalam Undang-Undang nomor 28 Tahun 2009 tentang pajak dan retribusi daerah, pemerintah daerah tidak diperbolehkan memungut pajak daerah selain yang telah ditetapkan dalam undang-undang. A kan tetapi demi memenuhi Pendapatan Asli Daerah (PAD), salah satu wewenang yang dapat dilakukan pemerintah daerah saat ini adalah perluasan basis pajak daerah yang sudah ada.

K ota M alang telah menjadi salah satu kota yang berkembang dalam bidang pariwisata dan pendidikan. Salah satu indikatornya adalah dapat dilihat dari semakin banyaknya hotel, restoran, dan tempat-tempat wisata yang menyajikan berbagai macam hiburan, serta sarana tempat bermukim para mahasiswa/pelajar dari luar daerah yang menyelesaikan pendidikanya di Kota Malang. Dengan berkembangnya dunia pendidikan, dimanfaatkan oleh para pengembang properti untuk menjalankan usahanya salah satunya dengan mendirikan usaha rumah kos. M elihat hal tersebut dinas pendapatan daerah Kota Malang kemudian mengeluarkan Perda N omor16 Tahun 2010 tentang pajak hotel kategori rumah kos.

$M$ asalah yang kemudian timbul adalahpelaksanaan peraturan ini terkesan belum berjalan sesuai ketentuan. Belum terbentuk pemahamanantara pihak pembuat peraturan yaitu pemerintah daerah dan pihak yang menjalankan peraturan (pemilik kosan). Selain itu, sosialisasi seputar pungutan pajak sejauh ini masih belum mampu menunjukkan eksistensi Perda N omor 16 Tahun 2010 tersebut.
B erdasarkan pengamatan pra penelitian, pemungutan pajak sesuai dengan Perda Nomor 16 Tahun 2010 di wilayah Kota Malang masih belum merata. Salah satu contoh, rumah kos di wilayah $\mathrm{Kel}$. Merjosari sudah membebankan pajak terhadap penghuni kost, sedangkan di K el. Ketawanggede (tempat tinggal Peneliti) masih dalam tahap survey oleh dinas terkait. Menjadi fakta yang menarik perhatian penulis hal apakah yang menyebabkan terjadinya ketidak merataan proses penarikan pajak rumah kos.

M unculnya permasalahan implementasi kebijakan ketika sosialisasi (komunikasi) antara pelaksana kebijakan yaitu pegawai dinas terkait dan subyek pajak yaitu pemilik dan penghuni kost, tidak berjalan dengan baik.

Implementasi kebijakan adalah yang paling berat, karena masalah $\leftarrow$ masalah yang kadang muncul tidak sesuai konsep dan ancaman utama adalah konsistensi. Nugroho (2012 : 681) menyampaikan bahwa secara prosentase, rencana adalah $20 \%$, implementasi $60 \%$, sisanya $20 \%$ mengendalikan implementasi. Fakta di atas menjadi kegelisahan penulis mengapa persoalan pemungutan pajak hotel kategori rumah kos di Kota Malang terkesan menjadi problematik dan sistemik.

Menurut Nugroho (2012 : 693) dijelaskan model-model atau teori yang membahas tentang implementasi kebijakan menurut para ahli. Salah satunya adalah model yang dikembangkan oleh Edward III, dimana keberhasilan implementasi kebijakan publik dipengaruhi oleh 4 (empat) faktor yaitu: a) Communication (K omunikasi), b) Resources (Sumber Daya), c) Dispositions (Disposisi) dan d) Bureaucratic Structure (Struktur Birokrasi).

K eempat faktor ini menjadi bahan analisa kritis dalam melakukan penelitian mengenai implementasi Perda Nomor 16 Tahun 2010 tentang pemungutan pajak hotel kategori rumah kos di K ota M alang. 


\section{KAJIAN TEORI}

\section{Administrasi Publik, Kebijakan Publik dan Implementasi Kebijakan Publik.}

Administrasi publik adalah proses dimana sumber daya dan personel publik diorganisir dan dikoordinasikan untuk memformulasikan, mengimplementasikan dan mengelola (manage) keputusan $\leftarrow$ keputusan dalam kebijakan publik (K eban, 2008 : 3). Chandle dan Plano dikutip oleh Pasolong (2008 : 7) juga menjelaskan bahwa "Administrasi Publik merupakan ilmu dan seni (science and art) yang ditunjukan untuk mengatur masalah publik (Public Affairs) dan berbagai tugas yang ditentukan.

Wiliiam N. Dunn menyebut istilah kebijakan publik dalam bukunya yang berjudul Analisis Kebijakan Publik, pengertiannya sebagai berikut : "Kebijakan Publik (Public Policy) adalah Pola ketergantungan yang kompleks dari pilihan-pilihan kolektif yang saling tergantung, termasuk keputusan-keputusan untuk tidak bertindak, yang dibuat oleh badan atau kantor pemerintah" (Dunn, 2003 : 132). Hersel Nogi S. Tangkilisan dalam bukunya yang berjudul Kebijakan Publik yang Membumi mengutip pendapat Thomas R. Dye yang mengartikan public policy is whatever governments choose to or not to do (Dye dal am Tangkilisan, 2003: $1)$.

B erdasarkan pengertian yang dikemukakan oleh Dye tersebut kebijakan publik maksudnya adalah apapun yang pemerintah pilih untuk melakukan atau tidak melakukan suatu tindakan. A nderson mengartikan kebijakan publik sebagai serangkaian tindakan yang mempunyai tujuan tertentu yang diikuti dan dilaksanakan oleh pelaku atau sekelompok pelaku guna memecahkan masalah tertentu (A nderson dalam Widodo, 2001 : 190).

Implementasi kebijakan publik dapat diartikan sebagai aktivitas penyelesai atau pelaksanaan suatu kebijakan publik yang telah ditetapkan/disetujui dengan penggunaan sarana (alat) untuk mencapai tujuan. Tachjan (2006 : 24).

K ebijakan publik yang dirumuskan dan diformulasikan melalui serangkaian proses kebijakan publik seperti dijelaskan sebelumnya jika tidak diimplementasikan maka kebijakan itu tidak berarti apa-apa dan tidak mempunyai dampak apa-apa. Kebijakan adalah hanya sebuah dokumen politik apabila ia tidak ikuti tindakan kongkrit. Samodra (1994: 34).

Implementasi kebijakan berarti berbicara dimana kebijakan itu dijalankan oleh aktor, organisasi, serangkaian prosedur, tehnik dan sumberdaya secara bersama-sama untuk dilaknasakan. Implementasi kebijakan merupakan tahapan paling krusial, Nugroho (2012 : 681) menyampaikan bahwa rencana adalah $20 \%$, implementasi $60 \%$, sisanya $20 \%$ mengendalikan implementasi. Kedudukan implementasi kebijakan adalah sangat krusial dalam proses kebijakan publik.

\section{Pemilihan Model Implementasi}

Pemilihan satu model tergantung masalah yang dihadapi karena isu yang relevan adalah kesesuaian antara implementasi dengan kebijakan itu sendiri. Pada dasarnya setiap masalah yang dihadapi dalam satu masyarakat membutuhkan model implementasi kebijakan yang berlainan. Pemilihan atas satu model tidak mendasarkan pada kategori label atau model kebijakan atas bawah atau sebaliknya, tetapi lebih pada aspek permasalahan yang dihadapi oleh obyek yang diteliti relevan dengan indikator yang ada. Memperhatikan apa yang kemukakan oleh (M C Laughlin 1987) dalam Cerna (2013: 18) mengatakan, "Local Capacity and will matter for policy success; adequate resources and clear goals are importandt too" maksudnya masalah kapasitas lokal, sumberdaya yang memadai dan tujuan yang jelas juga penting sebagai keberhasilan sebuah kebijakan. 
Keberhasilan implementasi menurut Merile S. Grindle (1980) dipengaruhi oleh dua variabel besar, yakni isi kebijakan (content of policy) dan lingkungan implementasi (context of implementation). V ariabel isi kebijakan ini mencakup : 1) sejauh mana kepentingan kelompok sasaran termuat dalam isi kebijakan; 2) jenis manfaat yang diterima oleh target group; 3) sejauh mana perubahan yang diinginkan dari sebuah kebijakan; 4) apakah letak sebuah program sudah tepat; 5) siapa pelaksana program; 6) sumberdaya yang dikerahkan untuk pelaksanaan program. Sedangkan $V$ ariabel lingkungan kebijakan mencakup: 1) seberapa besar kekuasaan, kepentingan, dan strategi yang dimiliki oleh para aktor yang terlibat dalam implementasi kebijakan; 2) karakteristik institusi dan rezim yang sedang berkuasa; 3) tingkat kepatuhan dan responsivitas kelompok sasaran.

\section{METODE PENELITIAN}

Jenis penelitian adalah deskriptif dengan pendekatan kualitatif. Penelitian ini dilakukan di Dinas Pendapatan Daerah Kota Malang sebagai pelaksana dari kebijakan pemungutan pajak kategori rumah kos sedangkan Kelurahan Kecamatan Lowokwaru adalah wilayah kecamatan yang memiliki sebaran populasi rumah tangga terbesar diantara kecamatan yang lain dan Kelurahan Ketawanggede sebagai wilayah terdekat dengan Universitas Brawijaya dan memiliki unit usaha rumah kos yang cukup banyak. Adapun pengumpulan data dilakukan melalui Wawancara(Interview) terhadap narasumber, Pengamatan (Observasi) selama berada di lokasi penelitian, dan Dokumentasi berupa gambar (foto) pelaksanaan proses pemungutan pajak hotel kategori rumah kos, data realisasi penerimaan pajak hotel kategori rumah kOS, daftar SOP pajak dan kumpulan peraturan-peraturan pajak. adalah:

Sumber dalam penelitian ini

1. O rang/I nformanmerupakansumberdata utama yang benar-benarmengetahui dan kompeten dengan masalah. Informan dalam penelitian ini adalah Ibu N selaku Kasubbag Umum Dinas Pendapatan Daerah Kota Malang dan Ibu $Y$ selaku Kasi Penetapan Dinas Pendapatan Kota Malang danPemilik K os selakuW ajibPajak.

2. Peristiwa, peristiwa yang diobservasi dalam penelitian ini adalah peristiwa serangkaian kegiatan sosialisasi, pembekalan staf dinas pendapatan, dan pertemuan-pertemuan ditingkat masyarakat.

3. Dokumen, berupa data-data tertulis berupa pedoman-pedoman pelaksanaan pajak hotel kategorirumahkos, arsip, dokumenresmilainnya.

Teknik analisa data yang digunakan dalam penelitian ini menggunakan model interaktif seperti yang digambarkan M iles dan Huberman, J ohnny Saldana (2014).

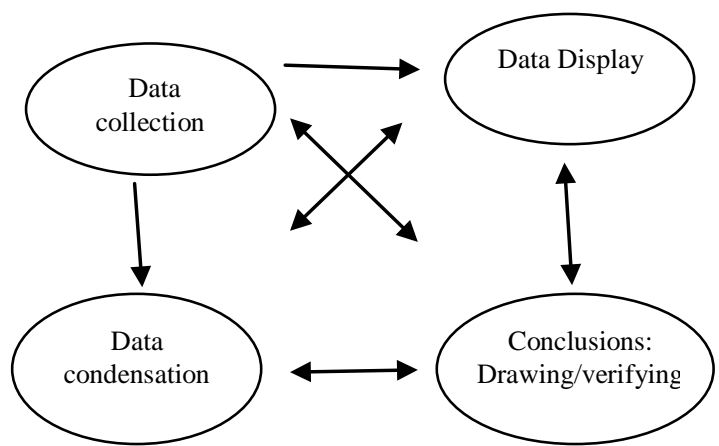

Gambar 1. K omponen A nal isis D ata M odel Interaktif

Sumber : M iles M.B \& Huberman J ohnny Saldana (Qualitative data analysis) 2014.

\section{HASIL DAN PEMBAHASAN}

Pajak hotel kategori rumah kos merupakan subbagian dari pajak hotel dengan kriteria rumah kos tersebut memiliki lebih dari 10 kamar hunian yang 
disewakan. Sedangkan didalam Perda Nomor 16 Tahun 2010 pasal 7 memaparkan tarif pengenaan atas pajak hotel kategori rumah kos ialah 5\% dari total penerimaan kos diterima oleh wajib pajak kos. Menurut hasil wawancara dari informan yang terkait dengan sistem pemungutan pajak hotel kategori rumah kos di Dinas Pendapatan Daerah Kota $M$ alang peraturan serta penjelasan secara tertulis terkait sistem pemungutan pajak hotel kategori rumah kos masih dalam lingkup yang sempit yaitu hanya menjelaskan tentang jumlah kamar kos yang dikenakan pajak hotel kategori rumah kos yaitu rumah kos yang memiliki lebih dari 10 kamar kos dan disewakan serta besarnya tarif pengenaannya yaitu $5 \%$ dari jumlah penerimaan kos tersebut.

Tabel 1. Laporan Realisasi Penerimaan Pajak Hotel Kategori Rumah K os Tahun A nggaran 2013-2015.

\begin{tabular}{|c|c|c|c|c|}
\hline \multirow{2}{*}{$N_{0}$} & $\begin{array}{c}\text { Tahun } \\
\text { Anggaran }\end{array}$ & Target (dalam Rp) & Realisasi (dalam Rp) & Prosentase (dalam \%) \\
\cline { 3 - 5 } & & 1 & 2 & $3=(2: 1) \times 100 \%$ \\
\hline 1 & 2013 & $64.469 .009,15$ & 67.843 .000 & $105.23 \%$ \\
\hline 2 & 2014 & $448.636 .145,83$ & 733.421 .338 & $163 \%$ \\
\hline 3 & 2015 & $1.000 .0000 .000,00$ & $1.738 .576 .832,50$ & $173,86 \%$ \\
\hline
\end{tabular}

Sumber : Dinas Pendapatan kota M alang

Tabel 1 di atas merupakan laporan realisasi penerimaan pajak hotel kategori rumah kos pada tahun 2013-2015. Dapat dilihat bahwa pada tahun 2014 bila dibandingkan dengan tahun 2013, terjadi peningkatan realisasi penerimaan pajak hotel kategori rumah kos sejumlah 665.578 .338 atau sebesar $57,77 \%$. Hal itu disebabkan karena pendataan terkait rumah kos sudah mulai berjalan serta gencarnya sosialisasi kepada wajib pajak. Kenaikan pada tahun tersebut sangat drastis. Pada tahun 2015, Dinas Pendapatan Daerah Kota $\mathrm{M}$ alang menargetkan target penerimaan dari pajak hotel kategori rumah kos sebesar 1.000.000.000,00. Sedangkan hasil penarikan yang bisa direalisasikan sebesar $\mathrm{Rp}$
1.738.576.832,50, terjadikan peningkatan yang cukup fantastis bila dibadingkan tahun 2014 sebesar 1.005.155.494,50 atau sebesar $137,05 \%$.

Pencapaian hasil realisasi penerimaan pajak hotel kategori rumah kos pada tahun 2015 yang melebihi target penerimaan membuat Dinas Pendapatan Daerah K ota $M$ alang untuk lebih intensif dalam memberikan sosialisasi kepada pemilik kos yang masih belum terdaftar sebagai wajib pajak hotel kategori rumah kos dan menjalankan kewajibannya membayar pajak kos terutang pada Dinas Pendapatan Kota Malang, oleh karena Kepala Dinas Pendapatan Daerah Kota M alang mengerahkan karyawan dan pegawai honorer Dinas Pendapatan Daerah Kota $M$ alang untuk melakukan sosialisasi dengan langsung terjun ke lokasi pemilik kos untuk mendata pemilik kos yang memiki kamar kos melebihi 10 kamar untuk mendaftrakan diri mereka sebagai wajib pajak hotel kategori rumah kos kota malang.

Hasil sosialisasi pajak hotel kategori rumah kos oleh Dinas Pendapatan Daerah Kota Malang yang didalamnya menjelaskan bahwa pihak Dinas Pendapatan Daerah Kota Malang mengerahkan karyawannya serta karyawan honorer mereka untuk melakukan pendataan wajib pajak hotel kategori rumah kos di kota malang dengan mendatangangi pemilik kos dengan door to door. Dari pelaksanaan ini diharapkan mampu menjaring pemilik kos yang belum terdaftar sebagai wajib pajak hotel kategori rumah kos.

Tabel 2. Data Jumlah Wajib Pajak Hotel Kategori Rumah Kos di Kota M alang Tahun 2013-2015

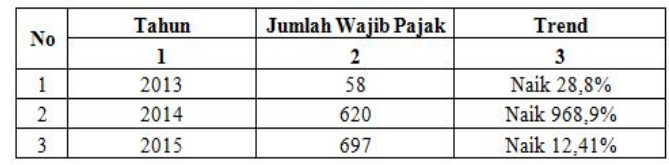

Sumber : Dinas Pendapatan kota M alang

Dari tabel 2 pada tahun 2014 terjadi peningkatan jumlah wajib pajak hotel 
kategori rumah kos sebesar 940,1\%. Sedangkan di tahun 2015 terjadi tren kenaikan masing-masing sebesar $12,41 \%$. $\mathrm{Hal}$ itu dikarenakan gencar sosialisasi dari petugas Dinas Pendapatan Kota Malang dan kian meningkatnya kesadaran para wajib pajak hotel kategori rumah kos di $\mathrm{K}$ ota $\mathrm{M}$ alang dari tahun ke tahun.

Peneliti menemukan fakta terkait implementasi Perda Kota Malang Nomor 16 Tahun 2010 tentang pemungutan pajak hotel kategori rumah kos di kota malang sesuai dengan faktor-faktor yang layak ditinjau sesuai dengan teori model implementasi menurut Edward III antara lain:

1. Komunikasi, permasalahan komunikasi yang terjadi antara aktor kebijakan dan target group (wajib pajak) yang menimbulkan kurangnya pemahaman Wajib Pajak mengenai pajak hotel kategori rumah kos. Permasalahan ini harus segera diselesaikan untuk dapat membentuk pemahaman dan kesadaran Wajib Pajak dalam melaksanakan pembayaran pajak hotel kategori rumah kos. Permasalahan ini disebabkan karena sosialisasi dan komunikasi yang kurang. Kemampuan komunikasi dari petugas Dispenda didukung instrumen lain seperti media massa yang harus dapat membentuk pemahaman publik terkait kebijakan hotel kategori rumah kos.

2. Sumberdaya, yang terdiri dari tiga sumber daya A ntara lain sumber daya manusia, sumber daya keuangan dan sumber daya sarana prasarana. Dari ketiga sumber daya yang telah dijabarkan dalam bab sebelumnya, semua sumber daya telah terpenuhi dengan baik. Jumlah personil, keterampilan dan tingkat pendidikan dari pelaksana kebijakan dinilai baik. Dukungan dana dari pemerintah berupa anggaran sendiri untuk melaksanakan kegiatan pemungutan pajak hotel kategori rumah kos juga tersedia dengan cukup. Sarana dan prasarana yang dimiliki oleh Dinas Pendapatan Daerah juga tersedia dengan baik.

3. Disposisi dinilai dari dua aspek, pertama terkait dengan tingkat kepatuhan pelaksana kebijakan dan kedua tingkat kepatuhan wajibpajak. Kepatuhan pelaksana kebijakan (actor kebijakan) dinilai sudah bagus karena adanya sikap mendukung dengan kebijakan pajak hotel kategori rumah kos guna meningkatkan PAD sesuai dengan tupoksi dari Dispenda. Sedangkan kepatuhan dari Wajib Pajak terkait kebijakan pajak hotel kategori rumah kos masih belum berjalan dengan baik. Kurangnya informasi terkait kebijakan, lambatnya proses sosialisasi kebijakan dari sejak diterbitkannya kebijakan dan keengganan Wajib Pajak untuk membayarkan pajaknya dinilai menjadi kendala yang masih harus dicarikan solusinya.

4. Struktur Birokrasi, dinilai dari dua aspek yaitu ketersediaan SOP Internal terkait koordinasi antar seksi dan pola hubungan kerja di dalam tubuh Dispenda. Terkait dengan hal pola hubungan kerja, Dinas Pendapatan Daerah Kota Malang memiliki pola hubungan kerja yang baik dan sesuai dengan bidangnya masing-masing. $\mathrm{Hal}$ ini menjadi unik ketika dilihat bahwa Dinas Pendapatan Daerah tidak memiliki SOP Internal yang berisi proses penyelenggaraan administrasi tentang tata cara melakukan pekerjaan, peraturan yang berisi koordinasi internal dari Dinas Pendapatan Daerah sebagai aktor yang berperan dalam kegiatan kebijakan pajak hotel kategori rumah kos.

Implementasi kebijakan akan berhasil jika didukung oleh faktor-faktor yang membuat kebijakan itu berjalan sesuai dengan yang diharapkan. Faktor-faktor itu berupa faktor pendukung dan penghambat. Dalam implementasinya faktor pendukung pemungutan pajak hotel kategori rumah kos adalah kualitas sumber daya manusia 
yang berkompeten, sistem komputer yang baik, dan sarana prasarana yang memadai. Sedangkan yang menjadi faktor penghambat pemungutan pajak hotel kategori rumah kos adalah peraturan yang belum efektif dan tingkat kesadaran pemilik kos yang rendah.

Kemudian dampak yang terjadi dari pelaksanaan kebijakan pemungutan pajak hotel kategori rumah kos adalah dampak positif yaitu dapat meningkatan PAD, dan lebih terdata-nya jumlah dan sebaran rumah kos yang ada di Kota Malang, sehingga di kemudian waktu akan dapat membantu pemerintah dalam melaksanakan kebijakan-kebijakan lain terkait rumah kos dan dapat mempersingkat waktu implementasinya. Sedangkan dampak negatif minimnya informasi yang sampai kepada pemilik kos sehingga dapat menimbulkan kemungkinan dampak yang lebih serius jika tidak segera ditanggulangi oleh pemerintah Kota Malang secara umum karena implementasi suatu kebijakan tidak akan dapat terlaksana secara maksimal jika target group masih memiliki penolakan terhadap kebijakan tersebut.

\section{KESIMPULAN}

Implementasi Perda Nomor 16 Tahun 2010 tentang pemungutan pajak hotel kategori rumah kos di K ota Malang sudah berjalan dengan efektif namun tidak efisien. Adapun faktor pendukung dan penghambat dari implementasi kebijakan tersebut. Penyebab utamanya adalah bentuk komunikasi antara implementor dan sasaran yang belum terjalin dengan baik. Peraturan yang lebih terperinci terkait penarikan pajak hotel kategori rumah kos juga dirasa diperlukan, karena akan membantu implementor dalam menjalankan kebijakan ini yang tergolong masih baru di kota Malang. Faktor pendukung pemungutan pajak hotel kategori rumah kos adalah kualitas sumber daya manusia yang berkompeten, sistem komputer yang baik, dan sarana prasarana yang memadai. Sedangkan yang menjadi faktor penghambat pemungutan pajak hotel kategori rumah kos adalah peraturan yang belum efektif dan tingkat kesadaran pemilik kos yang rendah.

\section{DAFTAR PUSTAKA}

Dunn, William. N. 2003. Analisis Kebijakan Publik. Y ogyakarta:Gadjah M Mada University Press

Grindle, M erilee S., (ed), 1980. Politics and Apolicy Implementation in the Third World, new jersey: Princetown University Press.

Keban, Jeremias T. 2008. Enam Dimensi Strategis Administrasi Publik: Konsep, Teori dan Isu. Y ogyakarta : Penerbit Gava M edia.

Cerna, Lucie. 2013. The Natureof PolicyChange and Implementation: A Review of Different Theoretical Approaches, Organization for economic co operation and development.

Miles, A. Michael Huberman, Johny Saldana. 2014. Qualitative Data Analysis, A rizona State U niversity U nited States Of A merica.

Nugroho, Riant. D. 2012. Kebijakan Publik, Formulasi, Implementasi dan Evaluasi. Jakarta, Elex M edia Computindo.

Pasolong, Harbani. 2008. Kepemimpinan Birokrasi. Bandung : A Ifabeta

Peraturan Daerah K ota M alang N omor16 Tahun 2010 tentang pajak hotel kategori rumah kos

Undang-U ndang nomor 28 Tahun 2009 tentang pajak dan retribusi daerah, pemerintah daerah

Samodra, W ibawa., Y uyun. P dan A gus P. (1994). Evaluasi Kebijakan Publik. Jakarta: Raja Grafindo Persada

Tachjan, H. 2006. Implementasi Kebijakan Publik, Bandung: AIPI 
B andung-Puslit, KP2W Lemlit UNPAD.

Tangkilisan, Hessel Nogi S. 2003.

Kebijakan Publik yang Membumi.

Y ogyakarta:Y ayasan Pembaruan

A ministrasi Publik Indonesia

(Y PAPI) \& Lukman Offset. 